\title{
Online Preconcentration Procedure for Chromium Speciation and Determination in Industrial Water Samples Using Flame Atomic Absorption Spectrometry
}

\author{
Shelja Tiwari, Niharika Sharma, and Reena SAXENA ${ }^{\dagger}$ \\ Department of Chemistry, Kirori Mal College, University of Delhi, Delhi-110007, India
}

\begin{abstract}
An online preconcentration system based on solid-phase extraction was developed for speciation and determinations of $\mathrm{Cr}$ in industrial water samples using flame atomic absorption spectrometry. A minicolumn packed with Amberlite XAD-16 loaded with salicylic acid was used to preconcentrate chromium species. All flow and chemical parameters that influence sorption were studied. The preconcentration factor and detection limit for the preconcentration time of $120 \mathrm{~s}$ were 79 and $0.10 \mu \mathrm{g} \mathrm{L}^{-1}$, respectively. The concentration of $\mathrm{Cr}(\mathrm{VI})$ species was calculated by the difference of the total $\mathrm{Cr}$ and $\mathrm{Cr}(\mathrm{III})$. The relative standard deviation (RSD) (five replicate of measurements) for 50 and $100 \mu \mathrm{g} \mathrm{L}^{-1} \mathrm{Cr}$ (III) solution was 1.2 and $1.0 \%$ respectively. The accuracy of the method was verified by analyzing a standard reference material (NIST SRM 1640a, trace elements in natural water). The proposed preconcentration method was successfully applied to the determination of $\mathrm{Cr}$ species in industrial water samples with satisfactory results.
\end{abstract}

Keywords Preconcentration, solid phase extraction, flame atomic absorption spectrometry, Amberlite XAD-16, salicylic acid

(Received April 16, 2016; Accepted August 5, 2016; Published December 10, 2016)

\section{Introduction}

Increasing pollution caused by heavy metals has become a challenging problem throughout the world. Their toxicity is directly associated with their solubility in aquatic systems, resulting in their accumulation in living systems throughout the food chain. In the last decade, chromium has gained considerable attention because of the difference in the toxicity of its two most common oxidation states- $\mathrm{Cr}(\mathrm{III})$ and $\mathrm{Cr}(\mathrm{VI}) . \quad \mathrm{Cr}(\mathrm{III})$ is biologically essential for living organisms, while $\mathrm{Cr}(\mathrm{VI})$ is cancer causing. ${ }^{1}$ The carcinogenic activity of $\mathrm{Cr}(\mathrm{VI})$ is because it can penetrate through the cell membrane and oxidize biological material. The industrial discharge from various tanning, pigments and electroplating industries introduces $\mathrm{Cr}(\mathrm{VI})$ in surrounding water bodies. ${ }^{2}$ Thus, it is extremely important to determine the chromium content in water. The permissible limit for chromium given by WHO is $0.05 \mathrm{mg} \mathrm{L}^{-1}$. Several spectro-analytical methods, such as graphite furnace atomic absorption spectrometry (GFAAS) ${ }^{4}$ flame atomic absorption spectrometry (FAAS), ${ }^{5}$ UV-visible (UV-Vis) spectrophotometry, ${ }^{6}$ inductively coupled plasma optical emission spectrometry (ICP-OES), ${ }^{7}$ inductively coupled plasma mass spectrometry (ICP-MS) ${ }^{8}$, have been used to determine chromium species in different samples. FAAS has become one of the popular techniques because of its low cost and easy operation. However, the direct determination of chromium is difficult at a trace concentration because of matrix interferences or loss of the analyte during the initial steps. ${ }^{9}$ Also, the direct determination

$\dagger$ To whom correspondence should be addressed.

E-mail: reenasaxena@kmcollege.ac.in of chromium species fails to differentiate between $\mathrm{Cr}$ (III) and $\mathrm{Cr}(\mathrm{VI})$. This problem can be solved by introducing a preconcentration step before the final determination of the chromium species. In this respect many chromatographic ${ }^{10}$ and non-chromatographic ${ }^{11}$ techniques have been reported. Solidphase extractants have been widely used to preconcentrate chromium species in various environmental and biological samples. ${ }^{12}$ The use of chelating resins as solid-phase extractants has found application in many systems. The advantages of using chelating resins are that they provide selectivity, and can interact with the analyte of interest by forming a chelate or by physical adsorption. ${ }^{13}$ However, solid-phase extraction (SPE) can be time and reagent consuming. The risk of contamination and loss of the analyte is also high if preconcentration is done manually. These issues can be resolved by coupling a flowinjection (FI) system to FAAS. This combination of FI-SPEFAAS offers advantages, like improved sensitivity, high sampling frequency, less reagent consumption and the removal of matrix ions. ${ }^{14}$ Solid-phase extractants based on polymers (Amberlite XAD series), ${ }^{15}$ alumina, ${ }^{16}$ silica, ${ }^{17}$ nanomaterials ${ }^{18}$ have been used for the speciation of chromium in FI-SPE-FAAS systems. The use of polymeric supports has gained attention because of their high surface area and hydrophobic character. Chelating resins with xylenol orange, ${ }^{19}$ 8-hydroxyquinoline, ${ }^{20}$ $\alpha$-benzoin oxime ${ }^{21}$ etc. as chelating agents have been used for the preconcentration of metal ions. In the presented work, salicylic acid immobilized on Amberlite XAD-16, was used for the preconcentration and speciation of chromium. Salicylic acid has carboxylic and phenolic groups that act as electron-pair donors, so they can interact with hard and intermediate cations. ${ }^{22}$ The developed FI-SPE-FAAS system was applied to industrial water samples. 


\section{Materials and Methods}

\section{Instrumentation}

AAnalyst 400 (PerkinElmer) FAAS with acetylene and air flow rates of 3.46 and $9.56 \mathrm{~L} \mathrm{~min}^{-1}$ was used as the detector. A chromium hollow cathode lamp operating at $10 \mathrm{~mA}$ with the wavelength set at $357.9 \mathrm{~nm}$ was used as the light source. The flow-injection system, FIAS 400 (PerkinElmer), was coupled to FAAS. This system was controlled by Winlab32 $2^{\mathrm{TM}}$ (Ver. 6.5.0.0266) software, which was installed in a personal computer. The infrared spectra were recorded on a PerkinElmer FT-IR spectrometer Model Spectrum RX-1 (resolution $4 \mathrm{~cm}^{-1}$, range $400-4000 \mathrm{~cm}^{-1}$ ). All $\mathrm{pH}$ adjustments were done on a $\mathrm{pH}$ meter Model LI-614 (ELICO Ltd., India).

\section{Reagents and materials}

All reagents used were of analytical grade. Ultrapure water from a Milli-Q water purification system (Merck Millipore) was used to prepare working solutions and dilutions. Amberlite XAD-16 was purchased from Sigma-Aldrich. Salicylic acid (Thomas Baker) was used as the chelating agent. Standard solutions of $\mathrm{Cr}(\mathrm{III})$ and $\mathrm{Cr}(\mathrm{VI})$ were prepared by the dilution of $1000 \mathrm{mg} \mathrm{L}^{-1}$ standard $\mathrm{Cr}(\mathrm{III})$ and $\mathrm{Cr}(\mathrm{VI})$ solutions traceable to NIST (Fluka). The $\mathrm{pH}$ adjustments were made using $0.1 \mathrm{~mol} \mathrm{~L}^{-1}$ $\mathrm{HCl}$, phosphate buffer (pH 6-8), $0.1 \mathrm{~mol} \mathrm{~L}^{-1}$ ammonium chloride buffer $(\mathrm{pH} 8-10)$ and a trisodium phosphate buffer (pH 11.7). The method was validated by analyzing the standard reference material NIST 1640a (Trace Elements in Natural Water), purchased from National Institute of Standards and Technology (NIST), Gaithersburg, MD, USA.

Synthesis of Amberlite XAD-16 functionalized with salicylic acid (SA-16) resin

The synthesis of Amberlite XAD-16 modified with salicylic acid (SA-16) was done according to a procedure given in literature. $^{23}$ The first step involves the nitration of Amberlite XAD-16, followed by reduction to give an aromatic amine. The diazotization of the amine was carried out at $0-5^{\circ} \mathrm{C}$, followed by immediate coupling with salicylic acid $(2 \mathrm{~g}$ in $2: 1$ wateracetic acid mixture). The reaction mixture was kept at $0-5^{\circ} \mathrm{C}$ for $24 \mathrm{~h}$. The resultant brown beads were filtered, washed with double-distilled water and stored in a desiccator until use.

\section{Column preparation}

In a glass mini-column $(3.0 \mathrm{~cm}$ length and $3.0 \mathrm{~mm}$ internal diameter), $78 \mathrm{mg}$ of synthesized SA-16 resin was packed. The column ends were sealed with cotton, and the column was washed with $2.0 \mathrm{~mol} \mathrm{~L}^{-1} \mathrm{HNO}_{3}$, followed by ultrapure water.

\section{Preconcentration procedure for $\mathrm{Cr}(\mathrm{III})$ determination}

The flow-injection preconcentration system involves two steps: loading and elution. These steps are computer controlled, which provides operational steps for chromium sorption and desorption. ${ }^{24}$ The preconcentration cycle is initiated with a prefill step to fill the tubes. In the loading step, a $\mathrm{Cr}$ (III) solution maintained at $\mathrm{pH} 6$ is pumped through Pump 1 for a preconcentration time of $60 \mathrm{~s}$. The retained $\mathrm{Cr}$ (III) ions from the column were then eluted in the elution step. The eluent was pumped through the column by Pump 2 for $30 \mathrm{~s}$. The height of the peak (absorbance) was recorded as the analytical signal. Prior to every measurement, a blank check was made. Three replicates of measurements were done for all solutions.

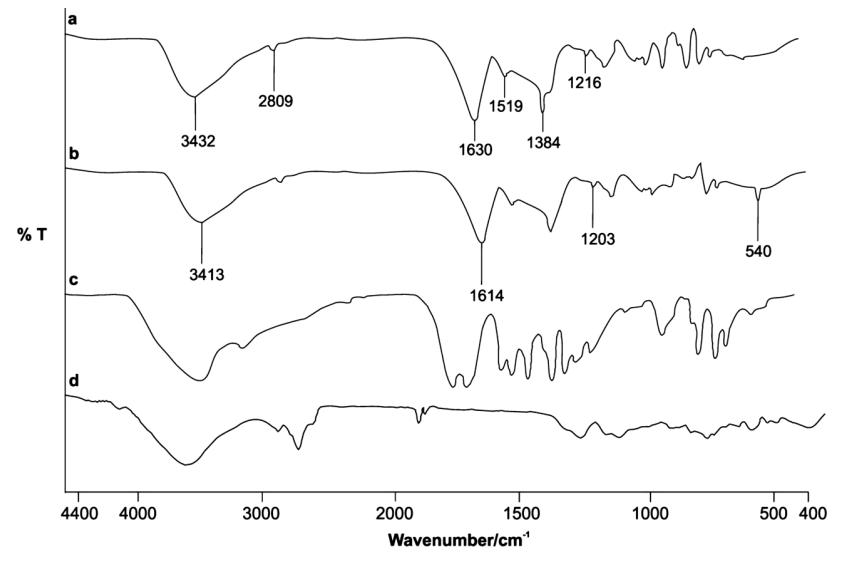

Fig. 1 Infrared spectra of a, Amberlite XAD-16 functionalized with salicylic acid (SA-16); b, Amberlite XAD-16 functionalized with salicylic acid after the sorption of $\mathrm{Cr}(\mathrm{III})$; c, salicylic acid; d, Amberlite XAD-16.

\section{Determination of total chromium}

The total chromium was determined by reducing $\mathrm{Cr}(\mathrm{VI})$ to $\mathrm{Cr}(\mathrm{III}){ }^{25}$ The reduction of $\mathrm{Cr}$ (VI) to $\mathrm{Cr}(\mathrm{III})$ was done by adding $0.1 \mathrm{~mL}$ of $5 \%$ hydroxylamine hydrochloride to a $25-\mathrm{mL}$ solution of $50 \mu \mathrm{g} \mathrm{L}^{-1} \mathrm{Cr}(\mathrm{VI})$. The solution was kept at room temperature for $45 \mathrm{~min}$, and was analyzed according to the optimized preconcentration procedure. The $\mathrm{Cr}(\mathrm{VI})$ concentration was calculated by subtracting the $\mathrm{Cr}$ (III) concentration from the total chromium concentration.

\section{Speciation of chromium in industrial water samples}

The developed method was applied for the speciation of chromium in industrial water samples. Three water samples were collected from the industrial areas around Delhi, India, and were acidified with conc. $\mathrm{HNO}_{3}$ before storage; $25 \mathrm{~mL}$ of each sample was filtered using $0.45 \mu \mathrm{m}$ pore size filter paper (Millipore). $\mathrm{Cr}(\mathrm{III})$ and $\mathrm{Cr}(\mathrm{VI})$ were determined as described in the sections above. The spike recovery studies were performed after spiking the water samples with certified $\mathrm{Cr}(\mathrm{III})$ and $\mathrm{Cr}(\mathrm{VI})$ solutions traceable to NIST.

\section{Results and Discussion}

\section{Characterization study of chelating resin (SA-16) FT-IR}

The characterization of SA-16 was done similar to as reported earlier. ${ }^{23}$ The spectrum of salicylic acid loaded Amberlite XAD16 showed bands at 3432, 1630, 1519, 1384 and $1216 \mathrm{~cm}^{-1}$. These appear to originate from the ligand molecule, and are characteristic of $\mathrm{O}-\mathrm{H}$ stretching, the carboxylic acid $\left(\mathrm{COO}^{-}\right)$ group, $-\mathrm{N}=\mathrm{N}-$ stretching, phenol group vibrations and $\mathrm{C}-\mathrm{O}$ stretching, respectively.22 This supports the loading of salicylic acid onto Amberlite XAD-16, as shown in Fig. 1a. After the sorption of $\mathrm{Cr}(\mathrm{III})$, the peaks of $\mathrm{O}-\mathrm{H},-\mathrm{N}=\mathrm{N}-$ and $\mathrm{C}-\mathrm{OH}$ were shifted by $5-10 \mathrm{~cm}^{-1}$; these were observed at 3413, 1614 and $1203 \mathrm{~cm}^{-1}$, respectively. The presence of a peak at $540 \mathrm{~cm}^{-1}$ corresponding to $\mathrm{Cr}-\mathrm{O}$ supports the complexation of $\mathrm{Cr}(\mathrm{III})$ with salicylic acid (Fig. 1b).

\section{Optimization of chemical and flow variables for Cr(III) preconcentration}

Salicylic acid is known to complex $\mathrm{Cr}$ (III) ion via salicylate sites. ${ }^{26}$ Optimization of the analytical parameters is a crucial 

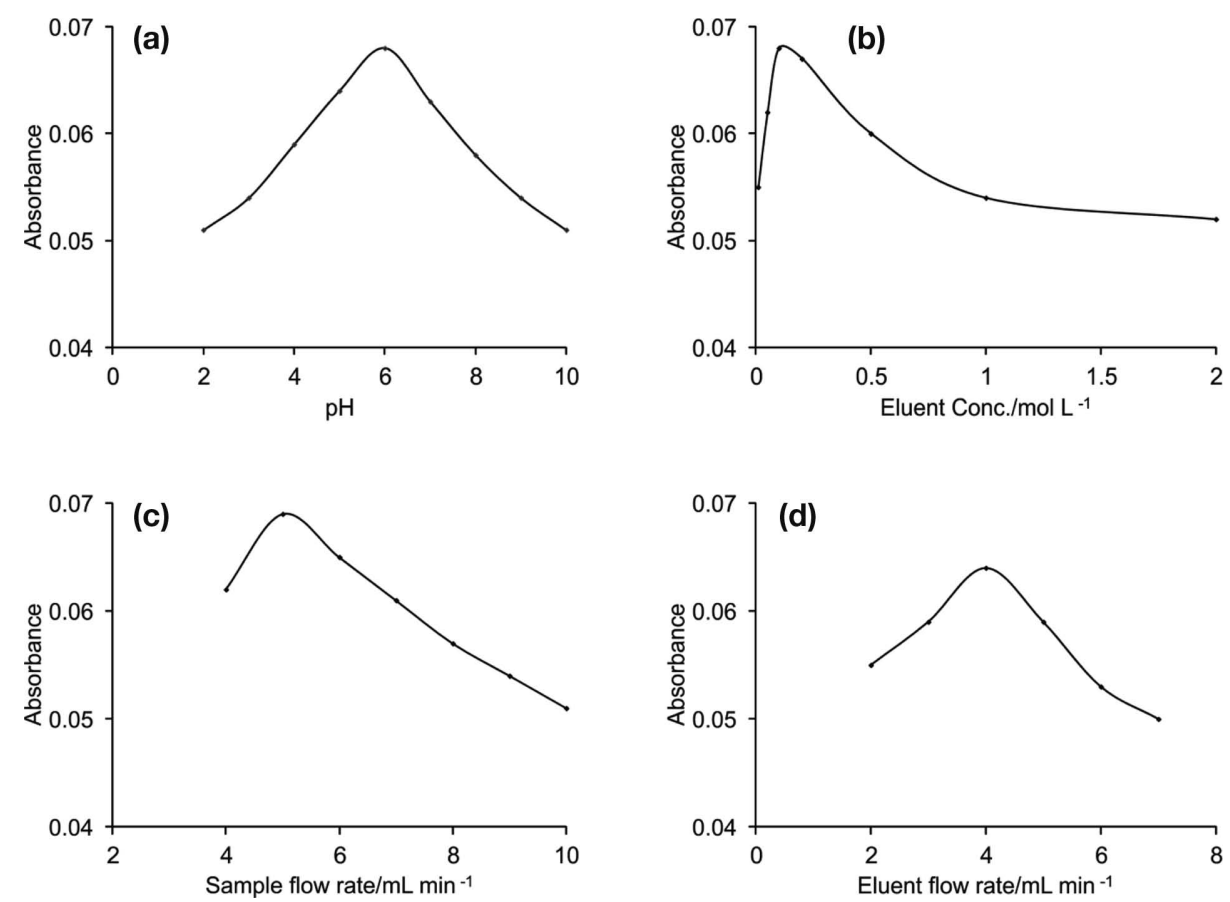

Fig. 2 Optimization of the preconcentration procedure of $\mathrm{Cr}(\mathrm{III})$. a, Influence of $\mathrm{pH} ; \mathrm{b}$, influence of the eluent concentration; $c$, influence of the sample flow rate; $d$, influence of the eluent flow rate.

step to ensure the maximum sorption of $\mathrm{Cr}$ (III) ions. Both the chemical and flow parameters were studied to achieve maximum efficiency.

Influence of sample acidity. The sample acidity is an important factor in deciding the retention of $\mathrm{Cr}$ (III) ions. In the $\mathrm{pH}$ range of $4-7, \mathrm{Cr}$ (III) is known to complex with organic molecules. ${ }^{27}$ Thus, the sorption of $\mathrm{Cr}(\mathrm{III})$ was studied in the $\mathrm{pH}$ range of 2 - 10. The maximum sorption was observed at pH 6 (Fig. 2a), so it was chosen as the optimum $\mathrm{pH}$ for further studies.

Influence of eluent concentration. Selection of the eluent is equally important, since it strips the sorbed $\mathrm{Cr}$ (III) ions from the minicolumn. The eluent study was done with different reagents, such as $\mathrm{HNO}_{3}, \mathrm{HCl}, \mathrm{H}_{2} \mathrm{SO}_{4}$ and $\mathrm{NaOH}$. $\mathrm{Cr}(\mathrm{III})$ was not quantitatively desorbed from the mini-column using $\mathrm{NaOH}$. Out of the remaining eluents, $\mathrm{HNO}_{3}$ gave the most reproducible results. Thus, the concentration of $\mathrm{HNO}_{3}$ was varied and the eluent study was done in the concentration range of $0.01-2.0 \mathrm{~mol} \mathrm{~L}^{-1}$. The maximum absorbance was achieved with $0.1 \mathrm{~mol} \mathrm{~L}^{-1} \mathrm{HNO}_{3}$. At concentrations beyond this, the absorbance obtained decreased steadily. Thus, $0.1 \mathrm{~mol} \mathrm{~L}^{-1}$ $\mathrm{HNO}_{3}$ was selected as the eluent for all subsequent studies (Fig. 2b).

Influence of sample and eluent flow rates. Optimization of the flow variables was done to ensure optimum contact time between $\mathrm{Cr}$ (III) and the minicolumn filled with chelating resin. Both the sample and the eluent flow rates were studied in the range of $2-7 \mathrm{~mL} \mathrm{~min}^{-1}$. The maximum absorbance was observed at sample (Fig. 2c) and eluent (Fig. 2d) flow rates of 5 and $4 \mathrm{~mL} \mathrm{~min}^{-1}$, respectively.

\section{Effect of concomitant ions}

The selectivity of the proposed method towards the sorption of $\mathrm{Cr}$ (III) ions was analyzed by studying the effect of the concomitant ions on the sorption of $100 \mu \mathrm{g} \mathrm{L}^{-1} \mathrm{Cr}$ (III) solution under the optimized conditions. A species is considered to be an interferent if it causes an error by $\pm 5 \%$. $\mathrm{Na}^{+}, \mathrm{NO}_{3}^{-}$and $\mathrm{Cl}^{-}$
Table 1 Analytical performance of the FI-SPE-FAAS system

\begin{tabular}{lcc}
\hline \multicolumn{1}{c}{ Parameter } & \multicolumn{2}{c}{ Optimum conditions } \\
\hline Preconcentration time $(\mathrm{PT}) / \mathrm{s}$ & 60 & 120 \\
Sample volume $/ \mathrm{mL}$ & 5 & 10 \\
Eluent volume $/ \mathrm{mL}$ & 2 & 2 \\
Linear range $/ \mu \mathrm{g} \mathrm{L}^{-1}$ & $0.7-560$ & $0.3-290$ \\
Limit of detection $/ \mu \mathrm{g} \mathrm{L}^{-1}$ & 0.2 & 0.1 \\
Limit of quantification $/ \mu \mathrm{g} \mathrm{L}^{-1}$ & 0.7 & 0.3 \\
Sample throughput $/ \mathrm{h}^{-1}$ & 30 & 20 \\
Enhancement factor & 37 & 79 \\
Regression equation & $A_{60}=$ & $A_{120}=$ \\
(6 standards, Cr(III) $/ \mu \mathrm{g} \mathrm{L}{ }^{-1}$, & $0.00259[\mathrm{Cr}(\mathrm{III})]$ & $0.00557[\mathrm{Cr}(\mathrm{III})]$ \\
with preconcentration) & -0.00314 & -0.00885 \\
Regression equation & $A=$ & $A=$ \\
(6 standards, Cr(III) $/ \mu \mathrm{g} \mathrm{L}{ }^{-1}$, & $0.00007[\mathrm{Cr}(\mathrm{IIII})]$ & $0.00007[\mathrm{Cr}(\mathrm{III})]$ \\
without preconcentration) & -0.00023 & +0.00025 \\
Correlation coefficient, $r$ & 0.9992 & 0.9993 \\
Precision, \%RSD & $1.2,[\mathrm{Cr}(\mathrm{IIII})]=$ \\
& $50 \mu \mathrm{g} \mathrm{L} \mathrm{L}^{-1}$ \\
& $1.0,[\mathrm{Cr}(\mathrm{IIII})]=$ \\
& $100 \mu \mathrm{g} \mathrm{L}{ }^{-1}$ \\
\hline
\end{tabular}

were tolerated beyond $5000 \mathrm{mg} \mathrm{L}^{-1}$, while $\mathrm{CH}_{3} \mathrm{COO}^{-}$and $\mathrm{I}^{-}$ were tolerated between $5000-1000 \mathrm{mg} \mathrm{L}^{-1}$. $\mathrm{Br}^{-}, \mathrm{SO}_{4}{ }^{2-}, \mathrm{NH}_{4}{ }^{+}$, $\mathrm{K}^{+}, \mathrm{Pb}^{2+}$ and $\mathrm{Ca}^{2+}$ were tolerated between $1000-100 \mathrm{mg} \mathrm{L}^{-1}$, while those tolerated below $100 \mathrm{mg} \mathrm{L}^{-1}$ were $\mathrm{Zn}^{2+}, \mathrm{Cu}^{2+}, \mathrm{Mg}^{2+}$, $\mathrm{Cd}^{2+}$ and $\mathrm{Al}^{3+}$.

Analytical performance of the FI-SPE-FAAS system

The analytical parameters for the proposed method were evaluated for $\mathrm{Cr}$ (III) sorption (Table 1). The reproducibility of the method was studied with 50 and $100 \mu \mathrm{g} \mathrm{L}^{-1}$; it was 1.2 and $1.0 \%$, respectively. The limit of quantification (LOQ) and the limit of detection (LOD) were calculated as the mean signal of 
Table 2 Analytical results for application to industrial water samples

\begin{tabular}{|c|c|c|c|c|c|c|c|}
\hline \multirow{2}{*}{ Sample } & \multicolumn{2}{|c|}{ Added $/ \mu \mathrm{g} \mathrm{L}^{-1 \mathrm{~b}}$} & \multicolumn{3}{|c|}{ Found/ $\mu \mathrm{g} \mathrm{L}^{-1}$ a } & \multicolumn{2}{|c|}{ Recovery, \% } \\
\hline & $\mathrm{Cr}(\mathrm{III})$ & $\mathrm{Cr}(\mathrm{VI})$ & $\mathrm{Cr}(\mathrm{III})$ & $\mathrm{Cr}(\mathrm{VI})$ & Total $\mathrm{Cr}$ & $\mathrm{Cr}(\mathrm{III})$ & $\mathrm{Cr}(\mathrm{VI})$ \\
\hline \multirow{2}{*}{$\begin{array}{l}\text { Anand Parbat industrial area, } \\
\text { Delhi, India }\end{array}$} & - & - & $30.2 \pm 4.72$ & $16.4 \pm 1.49$ & \multirow{2}{*}{$46.6 \pm 3.23$} & \multirow{2}{*}{96.0} & \multirow{2}{*}{98.6} \\
\hline & 20 & 20 & $48.2 \pm 2.03$ & $35.9 \pm 2.62$ & & & \\
\hline \multirow{2}{*}{$\begin{array}{l}\text { Seelampur industrial area, } \\
\text { Delhi, India }\end{array}$} & - & - & $24.2 \pm 2.01$ & $11.0 \pm 4.62$ & \multirow{2}{*}{$35.2 \pm 2.69$} & \multirow{2}{*}{100.9} & \multirow{2}{*}{100.6} \\
\hline & 20 & 20 & $44.6 \pm 2.42$ & $31.2 \pm 4.54$ & & & \\
\hline \multirow{2}{*}{$\begin{array}{l}\text { Wazirpur industrial area, } \\
\text { Delhi, India }\end{array}$} & - & - & $32.2 \pm 1.78$ & $15.1 \pm 3.62$ & \multirow{2}{*}{$47.2 \pm 2.02$} & \multirow{2}{*}{98.1} & \multirow{2}{*}{98.9} \\
\hline & 20 & 20 & $51.2 \pm 4.70$ & $34.7 \pm 1.40$ & & & \\
\hline
\end{tabular}

a. Confidence interval $95 \%$. b. Spiking with $\mathrm{Cr}(\mathrm{III})$ and $\mathrm{Cr}(\mathrm{VI})$ solutions traceable to NIST.

Table 3 Comparison of some reported on-line preconcentration FAAS methods with the proposed work

\begin{tabular}{|c|c|c|c|c|c|c|c|c|}
\hline Support & Chelating agent & Eluent & $\mathrm{PT} / \mathrm{s}$ & $\begin{array}{c}\text { Sample } \\
\text { volume } / \mathrm{mL}\end{array}$ & $\mathrm{RSD}, \%$ & $\begin{array}{c}\mathrm{DL} / \\
\mu \mathrm{g} \mathrm{L}^{-1}\end{array}$ & $\mathrm{PF}$ & Ref. \\
\hline Amberlite XAD-16 & Xylenol orange & $\mathrm{HNO}_{3}$ & 120 & 10 & 1.08 & 0.11 & 73 & 15 \\
\hline Amberlite XAD-16 & $\alpha$-Benzoin oxime & $\mathrm{HNO}_{3}$ & 300 & 10 & 1.03 & 0.14 & 76 & 21 \\
\hline Divinyl benzene & $\begin{array}{l}\text { Poly 2-(5-methylisoxazol)- } \\
\text { methacrylamide-co-2-acrylamido- } \\
\text { 2-methyl-1-propanesulfonic acid }\end{array}$ & $\mathrm{HNO}_{3}$ & 210 & 5.8 & 2.3 & 0.05 & 48 & 37 \\
\hline $\mathrm{FeC}$ nanoparticles & Chitosan & $\mathrm{HCl}$ & 4000 & 100 & 2.5 & 0.0524 & 100 & 32 \\
\hline Llama fibers & - & $\mathrm{NaOH}$ & 750 & 25 & 4.3 & 0.3 & 32 & 38 \\
\hline MWCNT's & - & $\mathrm{HNO}_{3}$ & 180 & 6 & 1.7 & 1.15 & 22 & 39 \\
\hline Nobias chelate PA-1 & - & $\mathrm{HNO}_{3}$ & 120 & 20 & 3.1 & 1.10 & 49 & 40 \\
\hline Silica & $\mathrm{Al}_{2} \mathrm{O}_{3} / \mathrm{TiO}_{2}$ & $\mathrm{HCl}$ & - & 20 & 2.4 & 0.66 & 18 & 41 \\
\hline Silica gel & Niobium(V) oxide & $\mathrm{HNO}_{3}$ & 120 & 15 & 4.6 & 0.34 & 23 & 42 \\
\hline Silica gel & Zirconium oxide & $\mathrm{HNO}_{3}$ & 225 & 15 & 3 & 1.9 & 21 & 43 \\
\hline UVM-7 & Amino silane & $\mathrm{NaOH}$ & - & 100 & - & 1.2 & 67 & 17 \\
\hline Amberlite XAD-16 & Salicylic acid & $\mathrm{HNO}_{3}$ & 120 & 10 & 1.0 & 0.10 & 79 & This work \\
\hline
\end{tabular}

PT, Preconcentration time; RSD, relative standard deviation; DL, detection limit; PF, preconcentration factor.

blank and equals to ten and three-times of the standard deviation, respectively. ${ }^{28}$ The LOQ and LOD $(n=7)$ for the preconcentration time of $120 \mathrm{~s}$ were 0.3 and $0.1 \mu \mathrm{g} \mathrm{L}^{-1}$, respectively. The preconcentration factor $(\mathrm{PF})$ is estimated as the ratio of the slopes achieved with and without preconcentration. The preconcentration factor achieved for a sample volume of $10 \mathrm{~mL}$ at the preconcentration time of $120 \mathrm{~s}$ was 79 .

\section{Sorption capacity of SA-16}

The sorption capacity is an important parameter, since it determines the amount of adsorbent required for the removal of specific amounts of metal ions. The batch method was applied to calculate the sorption capacity; $50 \mathrm{mg}$ of the synthesized resin was shaken with $50 \mathrm{~mL}$ of $100 \mathrm{mg} \mathrm{L}^{-1} \mathrm{Cr}$ (III) solution for $5 \mathrm{~h}$. This solution was filtered and the retained $\mathrm{Cr}$ (III) ions were eluted with $2 \mathrm{~mol} \mathrm{~L}^{-1} \mathrm{HNO}_{3}$. The filtrate was then analyzed by pre-calibrated FAAS. The sorption capacity of the SA-16 resin was $29.4 \mathrm{mg} \mathrm{g}^{-1}$, which was found to be better than previously reported systems. ${ }^{15,21,25,29-36}$

\section{Application of proposed method to industrial water samples}

The developed method was applied for the speciation of chromium in water samples. The results are given in Table 2. The spike recovery tests were performed by adding $20 \mu \mathrm{g} \mathrm{L}^{-1}$ of $\mathrm{Cr}$ (III) and $\mathrm{Cr}$ (VI) using $\mathrm{Cr}(\mathrm{III})$ and $\mathrm{Cr}(\mathrm{VI})$ solutions traceable to NIST. Recoveries $>95 \%$ was obtained for both chromium species.

\section{Method validation}

The accuracy of the proposed method was validated by analyzing NIST standard reference material 1640a (Trace Elements in Natural Water) for $\mathrm{Cr}(\mathrm{III})$. Three replicate measurements were taken for the SRM, and the results were calculated within the $95 \%$ confidence interval (mean \pm $2 \times$ standard deviation). No significant difference was observed between the obtained $\left(39.72 \pm 2.10 \mu \mathrm{g} \mathrm{L}^{-1}\right)$ and standard results $\left(40.54 \pm 0.30 \mu \mathrm{g} \mathrm{L}^{-1}\right)$. The recovery of $\mathrm{Cr}$ (III) was found to be $97.9 \%$.

\section{Conclusion}

The suggested method was successfully applied to the speciation of chromium in industrial water samples. The reported method has offered better results in comparison to other reported online system for chromium speciation in terms of the preconcentration factor, LOD, sample throughput, reproducibility, etc. (Table 3). The coupling of flow-injection with the FAAS system resulted in less reagent consumption, and lowered the risk of contamination from external sources. The sorption capacity is higher than other reported systems. The developed method is fast, automated and is selective towards $\mathrm{Cr}$ (III) in the presence of concomitant ions. The method was further validated by analyzing the NIST standard reference material 1640a, and can thus be applied for chromium speciation in different water samples. 


\section{Acknowledgements}

The authors are thankful to the Department of Science and Technology (DST) and the University Grants Commission (UGC), New Delhi, India for financial support. The authors are also grateful to the University Science Instrumentation Centre (USIC), University of Delhi, India for their instrumentation facility.

\section{References}

1. M. J. Marqués, A. Salvador, A. Morales-Rubio, and M. de la Guardia, Fresenius J. Anal. Chem., 2000, 367, 601.

2. L. Trzonkowska, B. Leśniewska, and B. G. Żyłkiewicz, Crit. Rev. Anal. Chem., 2016, 46, 305.

3. World Health Organization, "Guidelines for Drinking-water Quality", 4th ed., 2011.

4. H. M. Jiang, T. Yang, Y. H. Wang, H. Z. Lian, and X. Hu, Talanta, 2013, 116, 361.

5. M. Habila, Y. E. Unsal, Z. A. Alothman, A. Shabaka, M. Tuzen, and M. Soylak, Anal. Lett., 2015, 48, 2258.

6. E. Pehlivan and S. Cetin, J. Hazard. Mater, 2009, 163, 448.

7. Q. He, X. Chang, X. Huang, and Z. Hu, Microchim. Acta, 2008, 160, 147.

8. N. Zhang, J. S. Suleiman, M. He, and B. Hu, Talanta, 2008, $75(2), 536$

9. D. Kara, Anal. Lett., 2011, 44, 457.

10. J. Ščančar and R. Milačič, J. Anal. At. Spectrom., 2014, 29, 427.

11. K. Pyrzynska, Int. J. Environ. Anal. Chem., 2012, 92, 1262.

12. W. A. W. Ibrahim, L. I. A. Ali, A. Sulaiman, M. M. Sanagi, and H. Y. Aboul-Enein, Crit. Rev. Anal. Chem., 2014, 44 , 233

13. K. Pyrzynska, Trends Anal. Chem., 2012, 32, 100.

14. Z. Fang, "Flow Injection Atomic Absorption Spectrometry", 1995, John Wiley \& Sons Ltd, West Sussex, England.

15. R. Saxena, N. Sharma, and S. Tiwari, Anal. Sci., 2015, 31, 1303.

16. D. Das and M. Dutta, Desalin. Water Treat., 2013, 51, 6882.

17. H. Shirkhanloo, A. Khaligh, F. Golbabaei, Z. Sadeghi, A. Vahid, and A. Rashidi, J. Environ. Health Sci. Eng., 2015, $13,47$.

18. A. Moghimi, Afr. J. Pure Appl. Chem., 2013, 7, 146.
19. R. Saxena, S. Saxena, and P. Sarojam, At. Spectrosc., 2012, 33, 83.

20. R. Saxena and P. L. Meena, RSC Adv., 2014, 4, 20216.

21. S. Tiwari, N. Sharma, and R. Saxena, New. J. Chem., 2016, 40, 1412.

22. M. R. Shishehbore, A. Afkhami, and Hasan Bagheri, Chem. Cent. J., 2011, 5, 41.

23. R. Saxena and S. Singh, At. Spectrosc., 2013, 34, 155.

24. R. Saxena, S. Tiwari, and N. Sharma, RSC Adv., 2015, 5, 69196.

25. S. H. Ahmadi, A. M. H. Shabani, S. Dadfarnia, and M. Taei, Turk. J. Chem., 2007, 31, 191.

26. M. S. Aksoy and U. Özer, Chem. Pharm. Bull., 2004, 52, 1280.

27. J. Kotaś and Z. Stasicka, Environ. Pollut., 2000, 107, 263.

28. A. Shrivastava and V. B. Gupta, Chron. Young Sci., 2011, 2, 21.

29. Z. Li, X. Chang, Z. Hu, X. Huang, X. Zoua, Q. Wu, and R. Nie, J. Hazard. Mater., 2009, 166, 133.

30. R. K. Sharma and P. Pant, Int. J. Environ. Anal. Chem., 2009, 89, 503 .

31. M. Tuzen and M. Soylak, J. Hazard. Mater, 2006, B129, 266.

32. Y. Wu, Y. Jiang, D. Han, F. Wang, and J. Zhu, Microchim. Acta, 2007, 159, 333.

33. S. Vellaichamy and V. Palanivelu, Indian J. Chem., 2010, $49 A, 882$.

34. Ş. Tokalıoğlu, S. Arsav, A. Delibaş, and C. Soykan, Anal. Chim. Acta, 2009, 645, 36.

35. G. Çimen, Ş. Tokalıoğlu, İ. Özentürk, and C. Soykan, J. Braz. Chem. Soc., 2013, 24, 856.

36. P. Liang, Q. Ding, and Y. Liu, Sep. Sci., 2006, 29, 242.

37. Ş. Saçmacı, S. Şahan, Ş. Kartal, M. Saçmacı, U. Şahin, and A. Ülgen, Talanta, 2014, 120, 391.

38. R. G. Wuilloud, P. R. Monasterio, J. C. Altamirano, and L. D. Martínez, Talanta, 2009, 77, 1290.

39. H. Yu, W. Sun, X. Zhu, X. Zhu, and J. Wei, Anal. Sci., 2012, 28, 1219.

40. G. Giakisikli, P. Zachariadis, I. Kila, N. Teshima, and A. Anthemidis, Anal. Lett., 2016, 49, 929.

41. C. R. T. Tarley, G. F. Lima, D. R. Nascimento, A. R. S. Assis, E. S. Ribeiro, K. M. Diniz, M. A. Bezerra, and M. G. Segatelli, Talanta, 2012, 100, 71.

42. E. Carasek, E. Martendal, and H. F. Maltez, J. Hazard. Mater., 2009, 161, 450.

43. E. Carasek and H. F. Maltez, Talanta, 2005, 65, 537. 